\title{
Sri Aurobindo's Rodogune as a Tragic Play
}

Dr R. Subramony

Associate Professor \& HOD

Dept of English

The Madura College (Autonomous)

Madurai, Tamil Nadu, India

raaja.dhruv@gmail.com

Abstract

Sri Aurobindo wrote only one tragic play - Rodogune. It was written in Baroda. It is dated February 1906, just before he left Baroda for Bengal. It was first published in Sri Aurobindo Mandir Annual, 1958. It was also issued in book form in the same year.

Keywords- Syria, fate, free-will, Divine will.

Introduction

Sri Aurobindo wrote only one tragic play - Rodogune. It was written in Baroda. It is dated February 1906, just before he left Baroda for Bengal. It was first published in Sri Aurobindo Mandir Annual, 1958. It was also issued in book form in the same year.

In Rodogune, Sri Aurobindo, like this other plays, works on an existing theme to an invented one. The place is Syria. Sri Aurobindo goes to the historical Syria for this play. He has taken the theme from Appian's accounts of the wars of Syria. The main character is Cleopatra, the famous queen of Syria. It is most probable that Sri Aurobindo must have read about Cleopatra in Greek from Appian's The Syrian Wars. 
The Cleopatra of Appian's history is different from the Cleopatra of Shakespeare's Antony and Cleopatra. She is also different from the Cleopatra of Drydens All are Love.

Discussion

Dr. Prema Nandakumar states that Sri Aurobindo took hints for the story of his play from other accounts of Cleopatra's story also. She mentions the name of Justin, the accounts of Seleucids in the Mallabees and Plavius Josephus Early History of Jews and History of Jewish War ( 41 )

Sri Aurobindo has also drawn for this play from Corneille's Rodogune written in 1645 which "shows the steps whereby ambitious bring Cleopatra to crime. She poisons all rival claimants to power and finally herself ..." (9). Sheo Shankar Jaiswal states: "From a comparison of the story of Sri Aurobindo's Rodogune with that of Cornelles's Rodogune it seems that though Sri Aurobindo has borrowed the outline of the story from the historical sources of Appian, Justin and Josephus, etc but for many details in the play his indebted to Corneille is irrefutable." (96)

In his play Sri Aurobindo does not show the cruelty of Cleopatra. He does not depict the mother killing Selecus, her own son nor the cruelty of her own son, Antiochus, poisoning his mother to death. In Sri Aurobindo's play Cleopatra and her sons are projected as better human beings. In order to do this, Sri Aurobindo creates new characters, Phayllus and Cleone, the Chancellor and her sister respectively. Most of the villainy is attributed to Phayllus and Cleone. Cleopatra and her sons are absolved of the crimes.

Sri Aurobindo took from Appian, Justin and Josephus only the germinal idea of the play. Sri Aurobindo expresses in the play his philosophy. This has been enunciated in his The Life Divine and Savitri. Sir Aurobindo's philosophy is a product of realization. In a letter to Dilip Kumar Roy, Sri Aurobindo states, "Let me tell you in confidence that I never, never, never was a philosophy which is another story altogether. I knew precious little about 
philosophy before I did the Yoga and came to Pondicherry...” On Himself ( 37 ) He further states that there is very little argument in my philosophy... What is there is a harmonizing of different parts of a many sided knowledge so that all unites logically together. But it is not by force of logical argument that it is done, but a clear vision of the relations and sequences of the knowledge." (37) Sri Aurobindo wrote sixty-four pages a month of philosophy for the Arya not from the intellect. He states: "I had only to write down in terms of the intellect all that I had observed and came to know in practicing Yoga daily and the philosophy was true automatically" On Himself (37). His philosophy is based on knowledge, experience and realization.

Rodogune deals with the Sri Aurobindonian conception of Fate. It was opposed to the mechanical doctrines of materialism espoused in the West. He states:

The time has almost come when Indian no longer keep her light to herself but must pour it out upon the world. Yoga must be revealed to mankind because without it mankind cannot take the next step in human evolution of (The Harmony Virtue, 376)

He further states that, "Yoga gives us a means of escape from the dangeron doctrines of materialism which tend to subvert man's future and hamper his evolution." (The Harmony of Virtue, 375)

This truth discovered by the Indian Yogis can be found in Rodogune. Sri Aurobindo states that Yoga is necessary to see that "behind the visible events in the world, there is always a mass of invisible forces at work unknown to the outer mind of men." (Nirodbaran 121) In Yoga one, establishes a conscious connection with the Cosmic Self. With this, destiny can be altered. This view does not admit rigid predetermination. This is the power which "the Upanishads call the Brahman and the primal entity from which all things were born, in which they live and to which they return. (The Harmony of Virtue 377-78) 
The World is governed by the Will of this Cosmic Self. It is the Divine Will. The Universe is a fulfillment of the Divine Will. Nature, Prakrti works out the Divine Will. This Will is subjected to Law. Nature is bound by the Karmic Law. Sri Aurobindo states, "The whole causality may be defined as previous action leading to subsequent action, karma and karmaphala." (The Harmony of Virtue 377-78)

Vedanta recognizes not only fate but also free-will. Sri Aurobindo states, "This entity the Hindu teaching finds in the spirit ever free and blissful which is Supreme Soul of the universe. The spirit does not react; it is nature that contains the action. If the spirit asked it would be bound by its action." (The Harmony of Virtue 380) The spirit is free. Sri Aurobindo states:

The Thing that acts is Prakriti, Nature, which determines the svabhava of things and is the source and condition of Law or dharma. The soul or Purusha holds up the svabhava, watches and enjoys all the action and its fruit, sanctions the law or dharma. It is the King, Lord or Ishvara without whole comment nothing can be done by prakriti. But the King is above the law and free, (The Harmony of Virtue, 381)

The Indian view of fate gives recognitions to personal will as well. With endeavour, Sri Aurobindo believes that it is possible to modify fate. Spiritual, mental, Vital and physical forces fulfill Divine Will. In order to transcend Nature of Fate, man must surrender completely to the Divine. Sri Aurobindo states:

But in order to feel its mastery of Nature the human soul must put itself in communion with the infinite the Universal spirit. It's will must be one with the Universal Will. The human soul is one, with the Universal spirit but in the body it stands out as something separate and unconnected, because a certain freedom is permitted for it in order that svabhava of things may be diversely developed in different bodies. In using this freedom the soul may do it ignorantly, or knowingly. 
If it uses it ignorantly, it is not really free, for ignorance brings with it the illusion of enslavement to Nature. Used knowingly, the freedom of the soul becomes one with surrender to the Universal Will. (The Harmony of Virtue, 382).

True progress of humanity is liberation from bondage to Nature. Behind Fate is the Divine Will which works through Nature for mans progress. Life is not chance. It is planned in detail. The action of Rodogune symbolizes these facts of life. As a background to the study of the theme of Rodogune, Sri Aurobindo's views on Fate should be analyzed. Scattered throughout the play are his views on Fate. The contradiction between man's will and the will of the supreme soul causes suffering.

\section{Conclusion}

Sri Aurobindo's Play Rodogune is a parable on the working of Fate. It also glorifies love, the power and glory of love. Fate is the executive power of the Divine Will. It is an agent of spiritual evolution. Sheo Shankar Jaiswal states:

If it presents Fate as the great Victor and the Doer of all, it also sings of love as the great Redeemer, the savior of mankind from all ills and evils. (130) 


\section{Works Cited}

Aurobindo, Sri The Harmony of Virtue, The Collected works of Sri Aurobindo, Vol.3, Pondicherry, Sri Aurobindo Ashram, 1972.

Aurobindo Sri, On Himself, Vol.26, Pondicherry, Sri Aurobindo Ashram, 1972.

Jaiswal, Sheo Shankar, Sri Aurobindo's Plays, New Delhi, Classical Publishing Company, New Delhi, 1993

Nirodbaran, Correspondence with Sri Aurobindo, Pondicherry, Sri Aurobindo Ashram, 1969.

Nandakumar, Prema, "Rodogune: A Study”, Sri Aurobindo Circle, No 22, 1966 